\title{
Tunggu Tubang and Ulu Ayek: Social Mechanism of Sustainable Protected Forest Management
}

\author{
Edwin Martin $^{1 *}$, Didik Suharjito ${ }^{2}$, Dudung Darusman ${ }^{2}$, Satyawan Sunito ${ }^{3}$, Bondan Winarno ${ }^{1}$ \\ ${ }^{1}$ Environment and Forestry R\&D Institute of Palembang, Jl. Kol. H. Burlian Km 6.5 Palembang, Indonesia 30154 \\ ${ }^{2}$ Department of Forest Management, Faculty of Forestry, Bogor Agricultural University, Academic Ring Road, \\ Campus IPB Dramaga, Bogor, Indonesia 16680 \\ ${ }^{3}$ Department of Communication and Community Development Sciences, Faculty of Human Ecology, \\ Bogor Agricultural University, Kamper Road, Campus IPB Dramaga, Bogor, Indonesia 16680
}

Received April 5, 2016/Accepted May 11, 2016

\begin{abstract}
Practices and traditional knowledge of smallholder farmers living forests is a potential resource to enhance landscape management. However, knowledge of the smallholder-forest relationship is still rare to explore social mechanisms that allow their relationship lasting long. The research aims to obtain further understanding of the traditional practices of forest management in Semende, South Sumatera. We visited 32 villages in Semende and stayed on several occasions in the 10 villages. We used descriptive phenomenological approach to understand the social process of successful forest management by farmers. We find the key that leads to the relations of sawah-forest to be able to be maintained against changes, that is consistent attitude towards the core values of life, whatever happens and changes. Social mechanism in the form of practices of knowledge-institution-tunggu tubang is an integral package to ensure the sustainability of forest. The social mechanism is driven by the values of respect for the elderly, extended family, real work, the search for stability and serenity in the bonds of humanity. These findings may be valuable lessons for improving forest policy.
\end{abstract}

Keywords:protected forest, sawah, upland, smallholder, cultural value orientation

*Correspondence author, email:abinuha1976@yahoo.co.id,ph.: +62-8127865909

\section{Introduction}

Competition for land between agriculture and forest production results in agriculture to become the main driver of deforestation in the world for the last decade, which is approximately $80 \%$ (Kissinger et al. 2012). Conflict resolution between the conservation of natural resources and agricultural production attracted the attention of many parties. Baudron \& Giller (2014) discussed the criteria to be able to choose between land sparing and land sharing, as a model of harmony. Farming systems in developed countries is trying to find a mutually supportive relationship between the ecosystems conservation and agricultural production, especially for food (Harper \& Crane 2012). The land sparing concept that separates intensive farming and wild nature did not work to conserve local forest in Tanzania (Quandt 2016). However, smallholder farmers' tree-based systems are increasing recognized as efficient agricultural and natural resource production systems, which provide water conservation and other ecosystem services (Roshetko et al. 2008).

According to the study of de Snoo et al. (2013), the payment instrument is not a sustainable way to strengthen the quality of the landscape. They recommended to research knowledge-based policy instruments of cultural aspects, normative behavior or identity conception of farmers. Conserve natural resources by imitating the traditional management of anthropogenic habitat is a paradigm in developed countries (Wright et al. 2012). Practices and traditional knowledge are potential resources to manage the landscape better(Padoch \& Sunderland 2013).

von Heland \& Folke (2014) state that the conservation of ecosystem services by traditional communities in South Madagascar are generated by an interdependent socialecological system in which knowledge, practice, and beliefs coevolve. Unfortunately, the information from von Heland $\&$ Folke does not explain how the traditional system can withstand the pressure changes by development and increase of economic necessity. Tiwari et al. (2010) examined forest management practices by traditional society of Meghalaya in North-East India. They documented and analyzed traditional forest management system and its contribution to food security. However, the study did not explain how the system can be sustained in a dynamic situation. Knowledge of smallholder-forest relationship is still rare to explore the social mechanisms that allow their relationship last long. 
One location where farming communities live in close proximity with the forests is Semende in the uplands of South Sumatera. Semende people is a swidden agriculture community known to convert for agricultural use, so it is interesting to investigate how the forest in their native villages remain sustainable. As most communities in the uplands of Sumatera, they experience the process of development, affiliated with the market, and actively associated with various other communities. Of 32 Semende villages, 30 villages have the area of food production in the form of paddy field (sawah). The villages have sawahs to show the diversity of forest cover; there are some villages with intact natural forest cover in the upstream of villages, some villages display scattered natural forest cover, and there are some villages that did not look at all natural forests. Questions on performance are:

1 what are the social mechanisms that allow harmony between smallholder and forest,

2 what value orientation is held by Semende farmers that the practice of sawah-forest management remained persist in the midst of change,

3 what policies are needed to support the conservation of sawah-forests.

The research aims to obtain further understanding of the traditional practices of sawah-forest management in Semende, South Sumatera. The findings are expected to be a cornerstone of both the ethical and operational of forest management, especially for protection functions in Indonesia.

\section{Methods}

Theoretical framework Berkes (2008) offered the concept of traditional ecology knowledge (TEK) to understand and analyze local practices which are crucial in the conservation of natural resources. TEK is defined operationally as " $a$ cumulative body of knowledge, practice, and belief, evolving by adaptive processes and handed down through generations by cultural transmission, about the relationship of living beings (including humans) with one another and with their environment" (Berkes 2000). Not all TEK is enduring or ecologically wise; depending on the local social mechanism (Berkes et al. 2000). These social mechanisms may be thought of as a hierarchy that proceeds from local ecological knowledge to social institutions, to mechanisms for cultural internalization, and to world views (Figure 1). Knowledge and institutions require a mechanism for cultural internalization, so that learning can be encoded and remembered by social groups. World views or cosmology give shape to the cultural values, ethics, and basic norms of a society(Berkes et al.2000).

The main components for the creation of traditional practices and knowledge that generate ecological sustainability is a worldview in the form of proper environmental ethic (Berkes et al. 2000). Kluckhohn and Strodbeck in 1961 published a framework for analyzing the worldview of a person or society, as used by Uddin (2015) in his research. Kluckhohn and Strodbeck suggested 5 dimensions of value to be analyzed, such as orientation: man and nature, the nature of human life, time, activity, and relational.

Referring to the concepts of Berkes, Berkes et al., and Kluckhohn \& Strodbeck in advance, this study describes the harmonization of sawah-forest by smallholder of Semende and challenges in the midst of change and development. This description is taken from the context of farmers' experiences itself, thus an explanation of the relation of sawah-forest derived from their perspective

Semende people in the uplands of South Sumatera occupy 32 villages in 3 subdistricts in Muara Enim Regency (Figure 2). Most areas outside the residential areas are protected forests. The field research was conducted in December 2013 to August 2015.

We used descriptive phenomenological approach to obtain universal description of the farmers-sawah-forest relation. Descriptive phenomenology "calls for exploration of phenomena through direct interaction between the researcher and the objects of study...it calls upon investigators to set aside preconceptions through the procedures involved in bracketing...The lived experience itself, as described by participants, is used to provide universal description of the phenomenon" (Wojnar \& Swanson 2007).

TEK related cultural change can be more explained in a social unit such as villages (Reyes-García et al. 2014). In each Semende villages we asked about the phenomenon of forest: why did they conserve the forest? why were there no forest? We discussed this matter with village leaders and sawah farmers. Further, we decided to go back and lived in 10 villages representing the diversity of sawah-forest experiences. We had a conversation with participants to dig deeper into their experience managing sawah-forest: what had happened to the undisturbed or damaged forest? why there a sawah managed or abandoned? The conversation was mostly done in the field, walking transects from settlements,

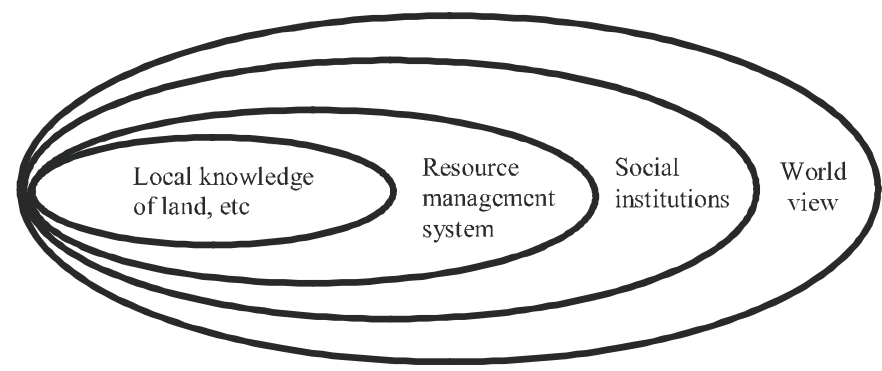

Figure 1 Level of analysis in traditional knowledge and management system (adapted from Berkes et al. 2000). 
sawah, into the forest. In addition to record all important conversations of the participants, we also recorded greetings, questions, and responses from people encountered every day in every village.

We followed the steps of phenomenological data analysis (Shosha 2012) to obtain units of meaning based on participants' awareness. We reconstructed the general meaning forest conservation mechanism based on respondent unit, then published a newspaper opinion column on the meaning of forest conservation. Reader of the column were asked to respond with their opinion regarding the essence of the meaning forest conservation, and thus partake in efforts to improve the validation of the study.

\section{Results and Discussion}

General description of farming communities and forests in Semende The villages in Semende are near a protected forest of Bukit Jambul. Semende peoples are primarily rice and coffee farmers (Table 1). In the study area, not all forests look like forests. The natural forests near the Semende villages are guarded by community, as upstream areas that provide water for their sawahs. Our informant responded to our study focus on their traditional forest: "Our forests are better than yours". The forest becomes destination for research on natural vegetation. During carrying out field research, we met 3 teams of researchers from various institutions that are looking at potential medicinal plants,

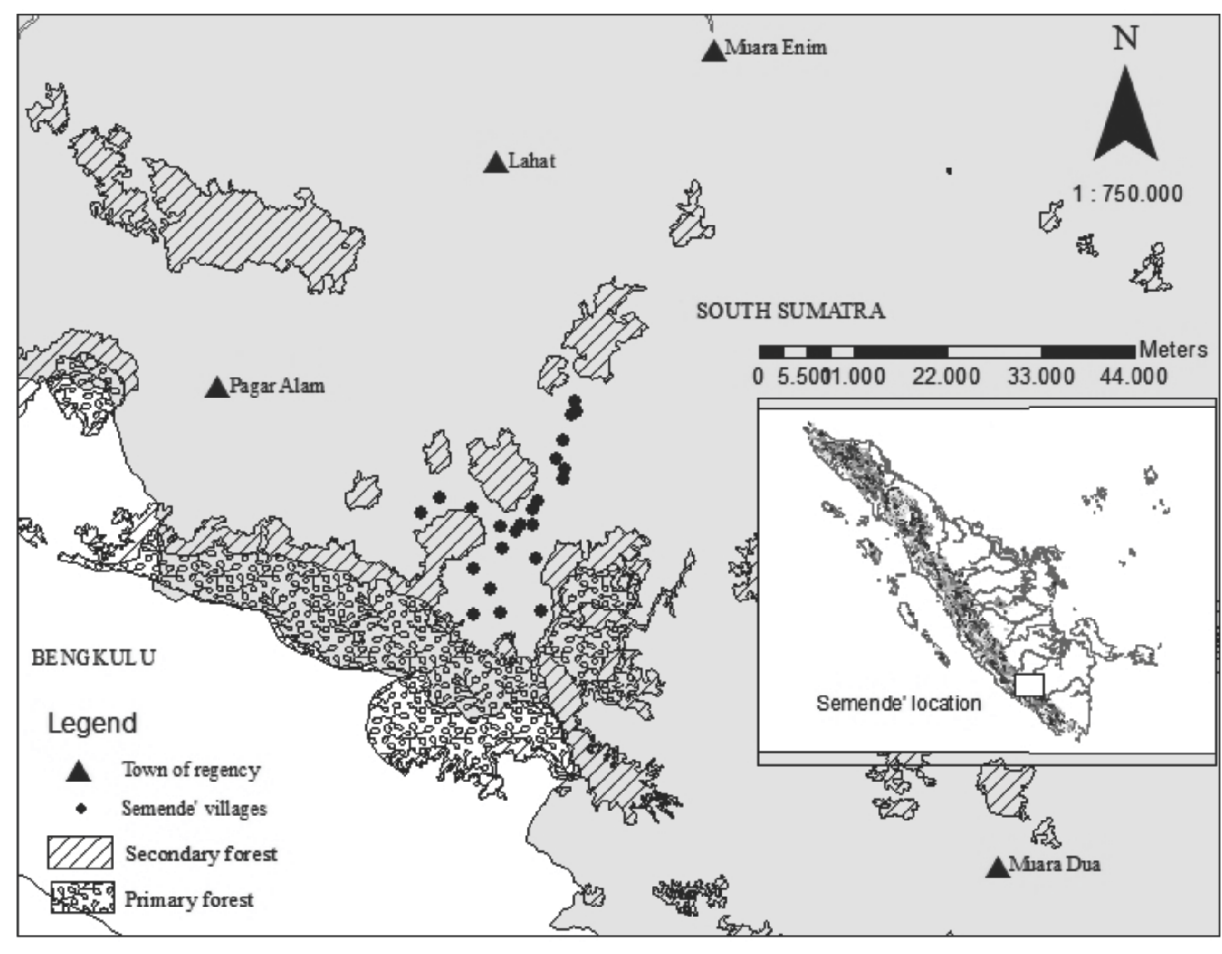

Source: Courtesy of Balai Pemantapan Kawasan Hutan Wilayah II Palembang, 2013

Figure 2 Villages of Semende communities in the uplands of South Sumatera.

Table 1 General description of villages in Semende, South Sumatera

\begin{tabular}{|c|c|c|c|}
\hline Biophysical and socio-economic conditions & $\begin{array}{l}\text { Semende darat } \\
\text { Ulu (SDU) }\end{array}$ & $\begin{array}{l}\text { Sub district of } \\
\text { Semende Darat } \\
\text { Tengah (SDT) }\end{array}$ & $\begin{array}{l}\text { Semende darat } \\
\text { Laut (SDL) }\end{array}$ \\
\hline Altitude $(\mathrm{m})^{\mathrm{a}}$ & $943-1,800$ & $997-1,024$ & $600-1,017$ \\
\hline Total villages & 10 & 12 & 10 \\
\hline Total population (people) $)^{\mathrm{a}}$ & 16,403 & 10,064 & 13,256 \\
\hline Sawah area $(\mathrm{ha})^{\mathrm{a}}$ & 1,828 & 1,219 & 1,120 \\
\hline Surplus of rice in $2014(\mathrm{~kg})^{\mathrm{a}}$ & 3,194 & 2,363 & 4,558 \\
\hline Coffee plantation (ha) $)^{\mathrm{a}}$ & 2,786 & 2,720 & 11,076 \\
\hline Villages dominated by $s a w a h^{\mathrm{b}}$ & 5 & 9 & 0 \\
\hline Villages dominated by coffee $e^{b}$ & 5 & 3 & 10 \\
\hline Villages with sawah directly irrigated from forest ${ }^{\mathrm{b}}$ & 7 & 4 & 4 \\
\hline Sawah converted into coffee garden (unit) ${ }^{\mathrm{b}}$ & 87 & 105 & 207 \\
\hline
\end{tabular}

Note: ${ }^{a}$ Data of BPS Muara Enim (2015), ${ }^{b}$ Data of field visits (2014/2015) 
non-timber forest products, and vegetation constituent to primary forests.

The phenomenon of the remnant natural forests that are managed by Semende indicates that traditional smallholders have developed a system considered to be more sustainable than state's scientific forest management. In fact, values, norms, and practices in traditional society still in accordance with the rules of conservation that are designed by state (Iswandono et al. 2015). In Semende, the performance of $u l u$ ayek forests is better than state's protected forest.

The existence of natural forest and land use in the landscape of Semende are described by study participants through their experience interacting and managing sawahirrigation-forests relation. The essence of the explanation of participant always starts from the aspect of tradition, then about the social aspect when facing anomalous facts, and ends with aspects of cultural values as a reference entity of their lives.

Forests are ulu ayek of our sawahs: traditional aspect The existence of undisturbed natural forests upstream of sawahs and villages in Semende are described by the farmers as a provider of water needs. Sawah in the hills require continous large quantities of water. The need is growing as populations increase and the forested areas are reduced. DG-1, a farmer from Danau Gerak Village said, "...before the village is crowded and not a lot of gardens, irrigation water used to be enough from the roots of trees around here, but after the people grew and the jungle was opened, the water source turned to the forests".

In the past, knowledge of the social-ecological interactions produced by the urge to live independently in isolation. Now, the knowledge is maintained and transmitted because sawah-irrigation-forest relationship has been proven to provide stability in the production of food from time to time. Semende people call an agricultural landscape unit an ataghan. Stability of ataghan sawahs is inseparable from the stability of the water produced by forests in the upstream.

Rice cultivation requires water management, thus they know and understand water conservation measures. Semende people call waterways in the forest that drain water from the spring as luang, irrigation canals as siring, irrigated channel divider called as tanggam, and springs called as mude ayek or entup-entup. DG-1 explained their reasons for prohibiting the destruction of forests, "...As long as the water is still flowing, the forest around siring from the first tanggam to mude ayek should not be cut down. When forests are cleared, the water in the luang will be drying, I am sure it would be dry. Water begins from entup-entup and roots of wood, most of the roots of timber..."

Natural forests also sporadically seen among coffee plantations. Forests are dispersed across the landscape jurang (steep slope). The Semende people categorize land into 4 types, jurang, tebing (strong slope), guring limauan (gentle slope), and datar (level). For them, jurang must be forested, because of landslides risk. Siring as waterways towards sawahs is generally through the hills in the category of jurang and tebing, so the area above the siring are traditionally determined as forest, called as ghimbe ulu ayek. If people depend their lives to resources that are in limited circumstances, then they have strong incentive to use resources sustainably (Berkes 2013). The concept of ulu ayek forest is similar to the definition of protected forests in Indonesian Forestry Law, but not identical.

\begin{abstract}
"Ghimbe ulu ayek border in our village is an area that has not been opened or cultivated by the people, it means that ancestor agreed the land should be left as ghimbe. Another border is the area where the water flows towards Siring. In our village there are approximately 500 ha of forest as ulu ayek. Ulu ayek means water is spilled into our territory and we are the people who take care of it (SG-1)"
\end{abstract}

TEK about the importance of the forest around the spring and ducts accumulate well over sawahs land tenure system. Sawah is property controlled by a tunggu tubang. Tunggu tubang is the eldest daughter in a family that is assigned to maintain, preserve, and exploit ancestral treasure, as family treasure. A tunggu tubang is forbidden to sell the sawah and may only cultivate it crops such as coffee. Some of sawahs are located at the edge of forests usually includes dry land plots that are planted by coffee, fruit trees, and small forest at the jurang. Forest can not be felled by tunggu tubang because it is a family asset. Traditional knowledge systems tend to have ethical and moral context, does not separate between culture and nature (Berkes 2008).

Ulu ayek forests are traditionally protected to be converted into agricultural land, but the villagers are allowed to use a limited amount of timber for domestic needs. The chief of ataghan holds customs authority to prohibit or allow logging in their ulu ayek forest. The tree use is typically done by the poor family or for the purposes of making a small house in sawah called dangau. The accumulation and transmission of plant species knowledge can take place by this resource use institutions. Michon et al. (2007) conceive this such management as domestic forests.

The rules of allowable cut trees are made by the member of an ataghan (individually called tuan sawah). This institution runs through the mechanism of monitoring that are held by datuk ayek or ketue siring, a supervisor who appointed by a tuan sawah meeting. SG-2 told the effectiveness of siring-forest monitoring in the Segamit Village, "...ataghan Endikat Bengkok has irrigation along $10 \mathrm{~km}$, Resam Padi along $3 \mathrm{~km}$, Padu Ringkih along $15 \mathrm{~km}$, each of them are supervised by ketue siring. If ulu ayek forest are interrupted that will be reported, then it is overrun by tuan sawah".

Ulu ayek forest's institutions are applied only to the forest directly as water sources or the siring's protection. Monitoring and implementation of the ban has strong social reasons for a direct link between sawah and the forest. In some villages, not all the ataghan sawahs take water from forest directly, but to get water from nearest river that springs are far outside the village (Figure 3 ). This such relation could not form sawah-forest institution.

"The hills opened by people for gardening coffee are upstream of Beghasang, Turunan, and Berujung; none of those rivers are becoming the water source of our sawahs. So, our community does not prohibit people from other villages to cut the forest. It is only Nibung upstream that is 


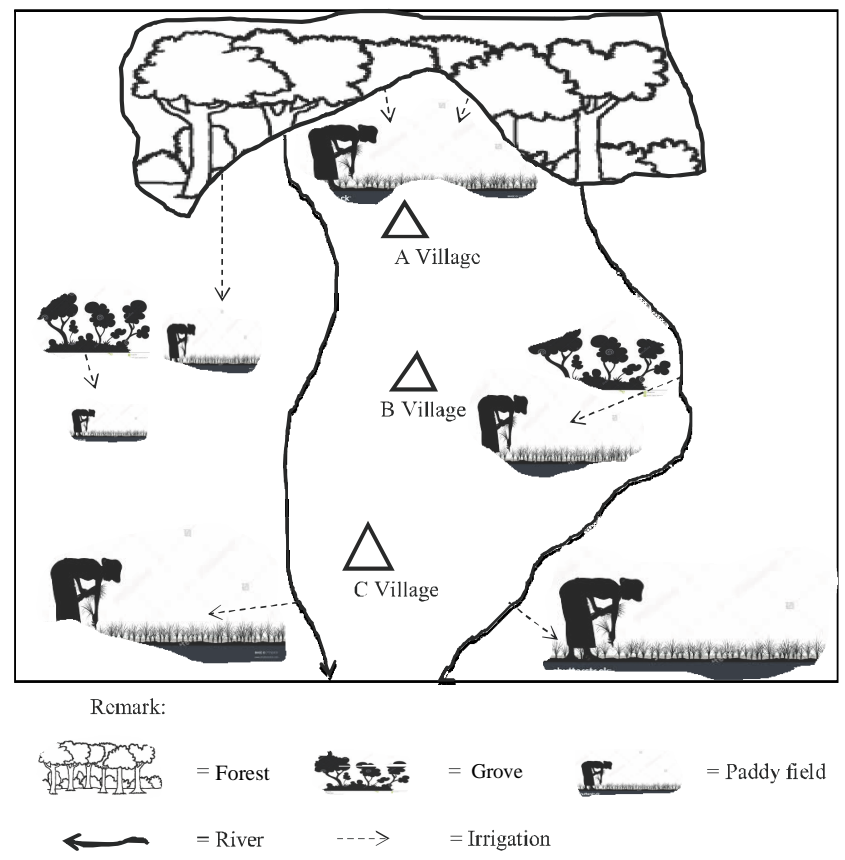

Figure 3 The illustration of sawah-forest relationship in Semende' villages.

supervised and guarded by people, as water source of sawahs. Once someone had tried to cut down the ulu ayek forest, the tuan sawahs come up with knives, they said'this is for you who will destroy our family' (PA-1).

Several groups of sawah-forest scattered in the villages are managed strictly. Tuan sawah prohibit extraction all kind of herbs in units of the remaining forest. Those sawahs rely on water source from spring within small forest, approximately 20-30 ha. As we are asked by informants to observe directly a small forest in area of coffee farms at the Aremantai Village, we met a farmer who were looking for firewood, then asked why he did not take wood from the forest, he said: "no one dares take anything, tuan sawah will take violent action for theft of wood, they know their own wood, it has been like that for a long time ago".

Ekawati \& Nurrochmat (2014) concluded that ecological uses improving the sustainability of protected forest, but the uses of economic ruin it. Previous descriptions show that for Semende people who are successful conserve forests, ecological and economic benefits are synergies; timber products and water used for domestic purposes, as capital basis in arranging other livelihood. They maintain the ecological benefits of forest because of the economic benefits. The flow of economic benefits are integrated with ecological benefits establish of livelihood for the people, something that is highly respected by Semende people.

Monitoring and sanctions are 2 important aspects which are often referred to as the critical success of sawah-ulu ayek forest. SG-2 said, "...ketue siring always keep an eye on the state of siring, even at work breaks days, so that the forests are always protected..." . Violations of the rules are always followed by sanctions. The application of sanctions is always involving the village head, as the formal and informal authority.
"There were incidents of tree felling in this ulu ayek forest. Suspected were reported by the datuk ayek to the village's head. Village head fined the violators. The money from the fine was used by datuk ayek to repair the siring”. (DG-1)

Ulu ayek forests which avoided from deforestation so far is an indication that the rule enforcement by tuan sawah run effectively and efficiently. This contrasts with the intervention of law enforcement by the government which is only effective in certain situations but it is meaningless in political and economic crisis or at the time of soaring coffee prices, and does not reach remote areas (Gaveau et al. 2009).

Sawah-forest link is missing: social relationships aspect Farmers experience shows that some ulu ayek forests have failed to sustainably. TEK which links sawah-forest relationship is faded away; the institutions were not established, defeated by other institutions, not considered by another ethnic, or is changing. This pattern of failed relationships can start from deforestation which leads to reducing sawah water or ruining the siring, and then followed by sawah abandonment. Semende people call abandoned sawah as tekelambu. If the sawah is already tekelambu, the forest in the upstream area no longer needs to be maintained.

TA-1 from Tanjung Agung Village told the reason behind the conversion of sawahs into coffee plantations. "Our sawahs at Batu Pikak could not be maintained anymore because of the water shortage. Water is reducing since the upstream of sawahs are opened to coffee plantations by residents of Tanjung Tiga...We could not stop deforestation since the forest is theirs. Who was the first to come and find life there is considered to be the proprietor of the land". So, ulu ayek forest does not become institutions when it was occupied by other residents before the establishment of sawahs. Ulu ayek forest is not under the authority of tuan sawah if they have no a history of siring development or never controlled it.

On several occasions of sawah-ulu ayek forests observation, we encountered cases of forest clearance for coffee plantations. The informants explained that the tuan sawah could not stop it because of historical reasons. Semende culture respects to history of land use; they call the forest that was once the coffee plantations as belukagh. Merely descendants may reuse the belukagh. In some places, belukagh institution defeat ulu ayek institution. Berkes et al. (2000) noted that not all traditional practices is ecologically wise.

Traditional institutions are not able to stop violations by farmers of other ethnic community in the border areas. TAB2 recount his experience facing the destruction of ulu ayek forests by a group of people from neighbor ethnic community. "We couldn't stop the actions of Padang Kandis people [Besemah ethnic] who felled the forest. Our community member is not dare to open the forest, because it respects tuan sawah, but they have nofeel that way. We avoid the quarrel, so the case we handed to the government". If the forest land already transformed into coffee plantations then that activity becomes socially acceptable. "We can not evict people who have planted coffee...if they lose their livelihood 
so this village will not be secure" (TAB-3).

Robinson et al. (2014) stated that less deforestation is not related to the form of tenure, but by security of tenure. If we learn from the case of broken social bonds that lead ulu ayek deforestation, then the state should give formal support to improve tenurial security, such as providing communal forest management rights certificates for the group of tuan sawah. Anyway, recognition and accommodation of government to local institutions is an important factor in achieving sustainable protected forest (Nursidah et al. 2012).

Several villages in Semende, such as the Tanjung Agung and Penindaian have experienced severe fires in their settlement, in the 1960s. This tragedy triggered mass migration to Lampung Province and surrounding areas. Tunggu tubang are forced to abandon their sawah and house. There is no longer of overseeing ghimbe ulu ayek. Forest destruction can't be avoided. Migration broke the sawahforest relationship. Without sawah as source of livelihood, local knowledge of sawah-forest relation is skipped, rule-inuse/institution as social mechanism (Berkes et al. 2000) has changed.

The changing of the economy needs, such as the increase of children school fees, purchase of household needs beyond food, and the desire for a better life encourages some tunggu tubang's families to migrate to other areas. MD-1 tries to understand the reasons why tunggu tubang migrate, "...sawah farming has no progress, it is difficult to have better life, if gardening coffee we could go to Hajj, buy a car, build homes, and send children to school...". Changing in life circumstances shift the priority of sawah farming became coffee plantations. However, these changes only on the ways to meet the economy needs, not shifting the main perspective. Orientation of life values is still preserved and taught through the existence of their social structure.

\begin{abstract}
"Nowadays, tunggu tubang are allow to work outside the sawah, with sawah cultivation done by others under sharing cropping system, such as sasih or maro. Parents will usually remind that the need of rice in a year will not decrease and tunggu tubang should always consult with the family when making decisions that are important to in their lives (TT-3).
\end{abstract}

Current knowledge emphasizes that poverty alleviation and livelihood diversification is the key to overcome the problem of the forests destruction by farmers (Meijer et al. 2015). Rice cultivation generates lower revenue than coffee farming. However, for Semende's sawah farmers, food stability and cultural obligations have higher value than money. Traditional knowledge of sawah-forests is not just knowledge but as a way of life, an authority system for resource use. The power of traditional knowledge is not in the sawah-forest specifically, but in the life processes that allow farmers and the extended family to maintain kinship.

Forest-sawah-tunggu tubang: the humanity binding Cases of ulu ayek forest and sawah conversion are a sign that TEK and institutions are not enough to explain why the natural forests around the Semende villages are sustainable. The facts show that there are some cases of ulu ayek forest destruction, but the history and the changes were never able to eliminate the phenomenon of sawah-forest interaction.
Sawah and tunggu tubang are like two sides of a coin. The culture of sawah-forest relation internalized the tunggu tubang mechanism, an entity that contains the doctrine, responsibilities, roles, and values. Once again, traditional knowledge systems tend to have ethical and moral context, does not separate between culture and nature(Berkes 2008).

Tunggu tubang not merely a term for the oldest daughter who was assigned to maintain the treasures of ancestors, but implies to continuously produce food for the family, especially for the elderly. The following explanation is commonly heard from Semende's family. "Tubang is a tube made of bamboo that has a cover. The benefit is to store daily foodstuffs. The tube is placed in the kitchen, so food becomes 'smoked' and 'preserved'. Therefore, tunggu tubang is also interpreted as waiting for the tube, keeping the food that is always available for family members who back home. The concept is derived in the form of sawah, food producers should last long. So, tunggu tubang is an entity that written by Berkes et al. (2000) as cultural framework for resource management.

Sawah is controlled by tunggu tubang after her marriage. Tunggu tubang's wedding ritual is different from the other children, because it is the highest accumulation of culture and values transmitting of Semende people. The task of tunggu tubang as unifier of the entire family of her maternal that is guided and supervised by meraje, brothers of mother. Meraje will ensure that the tunggu tubang executes custom commands to manage legacy, in the form of houses and sawah, without be sold. Tunggu tubang is obliged to take care of her parents and grandparents who live in the house. Tunggu tubang is a guarantee for family elder to be cared by their own daughter, so they can live peacefully in old age.

The common understanding states that the forest communities will support ecosystem services if their needs are accommodated (Muhamad et al. 2014). Participants description indicate that the guarantee of forest conservation and forest communities to support environmental services is not enough just from the aspect of needs of the community, but must involve a social mechanism that allows the intergenerational understanding, because each generations needs are different. Tunggu tubang house is a gathering place for the entire family of maternal; an interaction that teaches values to care for and respect the elderly, and also extended family. The main provision of this duty is food sovereignty.

Stability of sawah reflected in status and value. Sawah is cultivated by tunggu tubang but it is owned by many people and across generations, so the status of sawah is permanent. In Semende, sawah were converted into the coffee garden is still called sawah, even when transformed into the forest (tree-based) system. TA-2 recounted his experience as tunggu tubang. "When coffee prices increase, no sawahs converted to coffee plantations. For us, though we have a lot of money but we still need to eat rice, because money can't be eaten". TA-3 said the difference in value between sawah and coffee plantations, "...Rice is more valuable, the output and the price is stable, but coffee's prices could drop and the output depends on the season".

Institutions that protect forests were born from sawah culture. Sawah is ideal form of agrarian community who want to live independently and serene, derived from the 
concept of tunggu tubang. In general, these results strengthen the conclusions that were made by Von Heland \& Folke (2014), culture and ecosystems are interdependent; culture forms ecosystems, ecosystems provide services to livelihoods, the two were inseparable. However, we found that the key which causes both can survive from changes, namely the consistent attitude toward principal values of life, whatever happens and change.

Rice farmers in Semende hold on to their tradition, the task of the present, and hope for the future. Sawah is always associated with the orientation of the past and the present, as a capital for stepping to the future. They plant coffee to face the challenges of the needs for today and the future. TT- 1 said, "...we are still harvesting rice by hand, ani-ani. We sell rice only if it is urgent. Therefore, we still keep the rice that is harvested in 5 years ago. Rice stored at granary in sawah, called tengkiang. For us, selling rice is very urgent situation as a result of unavailable the source of other incomes". As a husband of tunggu tubang, TT- 1 has 2 ha of sawah and coffee plantations. He recently bought new land. "This land will be converted to a coffee plantations for the source of my livelihood, it will not be belong to the tung gu tubang".

In the terms of human relationship, Semende farmers hold the principle of respect for other people's work. This attitude can be seen from the tradition of mutual assistance in certain cases and tolerance to work for a livelihood. Mutual assistance or bebiye occurs in the rite of building house and planting coffee. When building roofs (negakka bubungan), all the heads of the household came to help, as a symbol of respect for those who want to meet their basic needs. Bebiye also occurs when a smallholder family has coffee farm establishment activity, at the time of planting. They appreciate the effort to achieve self-reliance. Kluckhohn and Strodbeck, as cited by Uddin (2015), categorized this relational orientation as collateral.

Respecting the work of others is practiced in many aspects of Semende people's lives. SG-1 explained about the omission of making new coffee plantations in the ulu ayek region. "The others ethnic use traditional system of belukagh balek ghimbe, where if someone abandoned his garden and it becomes forest, others have the right to control the land. For us, who first opened the forest then they has the right to use it again, even though the land has become forest". TAB-4 answered the question why they did not stop the destruction of protected forest areas. "We can only take care of the ulu ayek forest that is in our village. Forests that has been already converted to coffee plantations are difficult to reforest, because if it is done it will disrupt the lives of others". This respect for the work of others has also saved the ulu ayek forests until now, as stated many participants. "I let this land remain forested, because I still respect to the tuan sawah who cultivate paddy fields. If the sawah has not been cultivated, so I and others will use it as coffee plantation".

Other research mention that a conservation ethic and a culture of nature conservation in traditional communities of the Himalayas is inseparable from religion (Negi 2010). Previous statements showed the values that apply more generally to the farming communities (Table 2). Although Semende people are moslem, phenomenological approach in this study did not obtain expressions and meanings using religious arguments.

It is clear that the remaining natural forests in Semende are the outcome of local social mechanisms. Forest is designed by TEK that considers the natural biophysical properties, protected by sawah-forest institution based on TEK and social obligations, preserved by a mechanism for cultural internalization in the form of tunggu tubang, inside the range of the value orientation that appreciates the real work and prioritize food sovereignty (Figure 4). As mentioned by Berkes et al. (2000), those local social mechanisms inseparable, interrelated, and coevolving to the daily practices.

Ulu ayek forest management held by Semende farmers is

Table 2 Cultural value orientation of Semende farmers

\begin{tabular}{llll}
\hline Concepts & \multicolumn{2}{c}{ Description } \\
\hline Activity orientation & $\begin{array}{l}\text { Working to meet } \\
\text { livelihood (needs) }\end{array}$ & $\begin{array}{l}\text { Working to achieve a } \\
\text { and stable life serene }\end{array}$ & - \\
\hline Time orientation & Present & Past & Future \\
\hline Relational orientation & $\begin{array}{l}\text { Respecting consensus } \\
\text { among the farmers and } \\
\text { extended families } \\
\text { (collateral) }\end{array}$ & - & $\begin{array}{l}\text { Appreciating the work } \\
\text { of others } \\
\text { (individualistic) }\end{array}$ \\
\hline
\end{tabular}

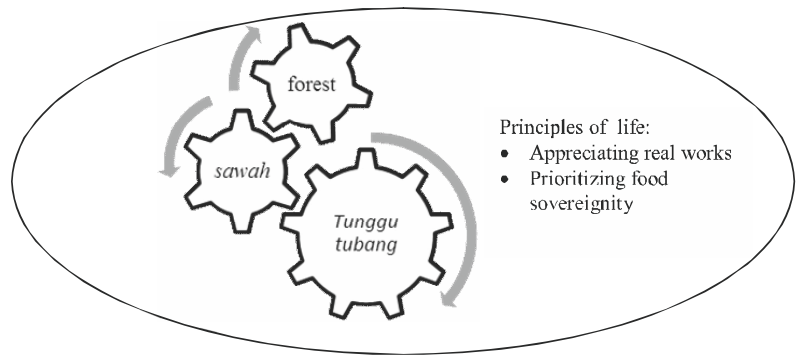

Figure 4 The local social mechanism of sawah-forest conservation by Semende people. 
a system similar to the proposed paradigm "domestic forest" by Michon et al. (2007). Conservation of forests for protection of water resources is widely practiced by various communities in Indonesia, such as Tobelo Dalam tribe in Halmahera (Tamalene et al. 2015), the indigenous village of Tenganan, Bali (Suryadarma 2012), the Nagari Simanau in West Sumatra (Hamzah et al. 2015), and Idas Village, Sanggau Regency (Damiati et al. 2015), and Kampung Kuta in Ciamis West Java (Aulia \& Dharmawan 2010). In "domestic forest" paradigm, forest management integrated with agriculture, regeneration occurs naturally, and the timber is not the main outcome of the forest. Learning from this research, protected forests conservation succeed not by "land sparing" but land integration, as part of smallholder life. Forests and sawahs objectively separate but subjectively both of them are integrated, inseparable.

\section{Conclusion}

Sawah culture delivers TEK of sawah-forest in Semende upland. This local knowledge generates institutions that protect the continuity of food production. Sawah-forest institution work effectively and last a long due to the existence of cultural framework in the form of tunggu tubang. The social mechanism in the form of practices of knowledgeinstitution-tunggu tubang is an integral package to ensure the sustainability of forest. The social mechanism is driven by the values of respect for the elderly, extended families, the real work, and the search for serenity in the bonds of humanity. If the local social mechanism is not running or one of the element of package is lost, the forests are threatened, because farmers do not have the sociological reasons for keeping forests from conversion desire.

\section{Recommendation}

Social mechanisms of ulu ayek forest conservation by Semende communities provide evidence of performance better forest management than of protected forest by the state. This is a lesson learned for policy improvement. The definition of protected forests should include the phrase "protection of life support systems for certain community", so that the object and the subject become obvious. Stipulation of protected forest should not deter use of resources, both timber and non-timber products for domestic needs of the community managers. Groups of people who recognized and empowered to manage protected forest are those that exhibit certain dependencies between the practices of everyday life and the existence of natural forests.

The state should give formal support to improve tenurial security, such as providing communal forest management rights certificates for the group of tuan sawah. Recognition and accommodation of government to local institutions is an important factor in achieving sustainable protected forest.

\section{References}

Aulia T, Dharmawan A. 2010. Local wisdom of water resource management in Kampung Kuta. Sodality 04(03):345-55.

[BPS Muara Enim] Badan Pusat Statistik Kabupaten Muara Enim. 2015. Muara Enim dalam Angka 2015. Palembang: BPS Muara Enim.
Baudron F, Giller KE. 2014. Agriculture and nature: Trouble and strife? Biological Conservation 170:232-45. http://dx.doi.org/10.1016/j.biocon.2013.12.009.

Berkes F. 2008. Sacred Ecology. 2nd edition ed. New York and London: Routledge Taylor \& Francis Group.

Berkes F. 2013. Religious traditions and biodiversity. Biological Conservation 6:380-86. http://dx.doi.org/10. 1016/b978-0-12-384719-5.00122-2.

Berkes F, Colding J, Folke C. 2000. Rediscovery of traditional ecological knowledge as adaptive management. Encyclopedia of Biodiversity 10:1251-62.

Damiati V, Lumangkun A, Dirhamsyah M. 2015. Partisipasi masyarakat dalam melestarikan kawasan hutan lindung gunung buduk sebagai sumber air bersih di Desa Idas Kecamatan Noyan Kabupaten Sanggau. Jurnal Hutan Lestari 3(1):142-49.

De Snoo GR, Herzon I, Staats H, Burton RJF, Schindler S, van Dijk J, Lokhorst AM, Bullock JM, Lobley M, Wrbka T, Schwarz G, Musters CJM. 2013. Toward effective nature conservation on farmland: making farmers matter. Conservation Letters 6:66-72. http://dx.doi.org/10.1111/j. 1755-263X. 2012.00296.x.

Ekawati S, Nurrochmat D. 2014. Hubungan modal sosial dengan pemanfaatan dan kelestarian hutan lindung. Jurnal Analisis Kebijakan Kehutanan 11(1):40-53

Gaveau DLa, Linkie M, Suyadi, Levang P, Leader-Williams N. 2009. Three decades of deforestation in southwest Sumatra: Effects of coffee prices, law enforcement and rural poverty. Biological Conservation 142(3):597-605. http://dx.doi. org/10.1016/j.biocon.2008.11.024.

Hamzah, Suharjito D, Istomo. 2015. Efektivitas kelembagaan lokal dalam pengelolaan sumber daya hutan pada masyarakat Nagari Simanau, Kabupaten Solok. Risalah Kebijakan Pertanian dan Lingkungungan 2(2):117-28

Harper M, Crane E. 2012. Balancing agricultural production and conservation? setting out the production and environmental challenges facing farming. International Journal of Agricultural Management 1(3):49-56

Iswandono E, Zuhud A, Hikmat A, Kosmaryandi N. 2015. Integrating local culture into forest conservation: A case study of the Manggarai Tribe in Ruteng Mountains , Indonesia. Jurnal Manajemen Hutan Tropika 21(21):55-64. http://dx.doi.org/10.7226/jtfm.21.2.55.

Kissinger G, Herold M, De Sy V. 2012. Drivers of Deforestation and Forest Degradation: A Synthesis Report for REDD+ Policymaker. Vancouver: Lexene Consulting.

Meijer SS, Sileshi GW, Catacutan D, Nieuwenhuis M. 2015. Farmers and forest conservation in Malawi: the disconnect between attitudes, intentions and behaviour. Forests, Trees and Livelihoods 8028:1-18 
Michon G, de Foresta H, Levang P, Verdeaux F. 2007. Domestic forests: A new paradigm for integrating local communities' forestry into tropical forest science. Ecology \& Society $12(2)$.

Muhamad D, Okubo S, Harashina K, Parikesit, Gunawan B, Takeuchi K. 2014. Living close to forests enhances people's perception of ecosystem services in a forestagricultural landscape of West Java, Indonesia. Ecosystem Services 8:197-206. http://dx.doi.org/10.1016/j.ecoser. 2014.04.003.

Negi CS. 2010. Traditional culture and biodiversity conservation: Examples from Uttarakhand, Central Himalaya. Mountain Research and Development 30(3):259-65. http://dx.doi.org/10.1659/MRDJOURNAL-D-09-00040.1.

Nursidah, Nugroho B, Darusman D, Rusdiana O, Rasyid Y. 2012. Institutional development to build a succesfull local collective action in forest management from Arau Watershed Unit Management Area, West Sumatera. Jurnal Manajemen Hutan Tropika 18:18-30. http://dx.doi.org/ 10.7226/jtfm.18.1.18.

Padoch C, Sunderland T. 2013. Managing landscapes for greater food security and improved livelihoods. Unasylva 64:3-13.

Quandt A. 2016. Farmers and forest conservation: How might land sparing work in practice? Society \& Natural Resources 1920:1-14. http://dx.doi.org/10.1080/0894 1920.2015.1095381.

Reyes-García V, Paneque-Gálvez J, Luz AC, Guèze M, Macía MJ, Orta-Martinez M, Pino J. 2014. Cultural change and traditional ecological knowledge: An empirical analysis from the Tsimane' in the Bolivian Amazon. Human Organization 73(2):162-73. http://dx.doi.org/10.17730/ humo.73.2.31nl363qgr30n017.

Robinson BE, Holland MB, Naughton-Treves L. 2014. Does secure land tenure save forests? A meta-analysis of the relationship between land tenure and tropical deforestation. Global Environmental Change 29:281-93. http://dx.doi.org/10.1016/j.gloenvcha.2013.05.012.
Roshetko JM. Snelder DJ, Lasco RD, Noorwijk M van. 2008. Future Challenge: A Paradigm Shift in the Forestry Sector. In: Snelder DJ, Lasco RD, editors. Smallholder Tree Growing for Rural Development and Environmental Services. Amsterdam: Springer Science+Bussiness Media.

Shosha GA. 2012. Employment of Colaizzi's strategy in descriptive phenomenology: A reflection of a researcher. European Scientific Journal 8(27):31-43.

Suryadarma IGP. 2012. Peran hutan masyarakat adat dalam menjaga stabilitas iklim satu kajian perspektif deep ecology (Kasus Masyarakat Desa Adat Tenganan, Bali). In: Konservasi Flora Indonesia Dalam Mengatasi Dampak Pemanasan Global. Yogyakarta: Universitas Negeri Yogyakarta

Tamalene NM, Muhdhar M, Robo T. 2015. Climate changes mitigate anticipation strategy based on local wisdom-a study of Tobelo Dalam Tribe. Journal of Biology and Earth Science 5(1):40-48.

Tiwari B, Tynsong H, Lynser M. 2010. Forest management practices of the tribal people of Meghalaya, North-East India. Journal of Tropical Forest Science 22(3):329-42.

Uddin ME. 2015. Exploration and implication of value orientation patterns in social policy-practice with ethnic communities in Bangladesh. Global Social Welfare 2(1961):129-38. http://dx.doi.org/10.1007/s40609-0140018-5.

von Heland J, Folke C. 2014. A social contract with the ancestors-Culture and ecosystem services in southern Madagascar. Global Environmental Change 24:251-64. http://dx.doi.org/10.1016/j.gloenvcha.2013.11.003.

Wojnar DM, Swanson KM. 2007. Phenomenology an exploration. Journal of Holistics Nursing 25(3):172-80. http://dx.doi.org/10.1177/0898010106295172.

Wright HL, Lake IR, Dolman PM. 2012. Agriculture-a key element for conservation in the developing world. Conservation Letter 5:11-19. http://dx.doi.org/10.1111/j. 1755-263X.2011.00208.x. 